\title{
A Mailman to make Government Understand: The Calypsonian (Chalkdust) as Political Opposition in the Caribbean
}

\section{DAVID HINDS}

\section{Introduction}

Caribbean popular music has served multiple functions. First, it has served as a source of collective memory. In this regard, it has been both a chronicle of the past and a form of positive reconstruction of that past. The constant reference to slavery in the music is an example of this reconstruction-reliving the past as a lesson for the present and the future. The music also reconstructs slavery and colonialism as sources of African fortitude and chronicles the day to day lived experience of the peoples of the region and their interaction with the world. This record of the past then becomes a large part of the region's collective memory. As Saunders observes:

As an integral part of the institutional memory of the Caribbean region, music is an invaluable medium for maintaining a critical perspective on society by keeping contributions and controversies alive for future generations to learn from, borrow and ultimately, even revise. Finally when the memory becomes susceptible to time, distance and the imagination, music is one of the "sign-posts" that allows us to reconstruct our past out of the splintered recollections in the recesses of our minds and bodies. ${ }^{1}$

Going hand in hand with the role of collective memory, Caribbean music also serves the function of affirmation of identity, a critical role given the erasure of the African identity that occurred during the period of enslavement and colonialism. The music then becomes an important tool in the quest for reclaiming history and identity. Finally, Caribbean popular music has been a form of resistance against racial, class, and imperialist domination. By highlighting the various forms of inequality and oppression the music becomes the collective resistance that rebukes the oppressor in what Black Stalin calls "resistance language."

This paper presents the calypso and the calypsonian in this context. It treats the calypso not just a mirror of society but, more importantly, as an advocate of social and political change. The calypsonian, the music maker, is portrayed as an agent of resistance, affirmation, and nation, who assumes the role of the wise man or woman messenger. This messenger simultaneously teaches, defends, affirms, reports, interprets, attacks, scolds, and condemns. The messenger's creativity, then, is inextricably linked to the lived realities of the marginalized masses and their quest for self-definition and freedom.

Pratt (1990) locates music in a larger socio-political context that may or may not reflect the conscious intent of the artist. He privileges this political function of music, which he describes as "political behavior" and which according to him "arises out of the unique ability of music seemingly to create a kind of spontaneous collective identity or facilitate the investment of people's psychological energies." ${ }^{2}$ Echoing the relationship between community and music, Mattern observes that "music provides a form of

\footnotetext{
${ }^{1}$ Patricia Saunders, "Mapping the Roots/Routes of Calypso in Caribbean Literary and Cultural Traditions," in Pauchet Paquet et al Music Memory Resistance: Calypso and the Literary Imagination (Kingston: Ian Randle Publishers, 2007), xx.

${ }^{2}$ Ray Pratt, Rhythm and Resistance: Explorations in the Political Uses of Popular Music (New York: Praeger Publishers, 1990), 4.
} 
communication through which the commonalities of community are created and discovered." ${ }^{3}$ He argues that among other things music "serves as a record of a civilization or community" and as historical and political memory. Turning his attention to "political" or "protest" music he locates it within the context of the class struggle or the struggle between the dominant groups and the dominated ones. As he observes: "typically the intent of protest musicians is to oppose the exploitation and oppression exercised by dominant elites and members of dominant groups." The music, therefore, becomes part of the larger cultural and political resistance out of which notions of freedom and identity emerge.

This socio-political role of music is especially applicable to African diasporan communities which have had to confront varying forms of subjugation from slavery through colonialism and neo-colonialism. Central to the slave experience was the erasure of culture and the dehumanization of the enslaved. Logically, then, the preservation of culture has been central to the resistance against this dehumanization. In this regard, black culture, in particular black music, is rooted in this resistance against inhumanity and the quest for humanity. The music arises out of the social struggle and records, defines and mobilizes for it.

Rex Nettleford describes Caribbean popular music as the "raw stuff of protest" that has "gone beyond fulfilling the universal need for entertainment to attract acute interest in its deeper significance for Jamaican and Caribbean cultural search for form and purpose." ${ }^{5}$ Michael Manley captures this sentiment in the following quote:

Through it all, music was one of the means through which the slave held on to the past and endured the present. Any discussion of the blues, the calypso, and the reggae begins at this point. Like all folk music, it is all essentially commentary; but what is unique about this commentary is it reflects in every thought, in every musical pulse, something to do with survival and accommodation. The children of the diaspora struggle for a place in society to this day. Worse, they struggle for their identities, mislaid as the slave ships made their way to the New World through the middle passage. Therefore, their commentaries must deal with these realities. ${ }^{6}$

Chalkdust (1986) and Warner (1985) also identify the role of historical memory with particular reference to the calypso. They observe that the political history of most Caribbean countries can be traced through the calypso. According to a former Chief Minister of Trinidad and Tobago, Albert Gomes, "Long after most of us are forgotten, certain calypsos will survive as the only reminders to some later generation of how we loved, labored and sinned."

\section{The Political Calypso}

Saunders et al identifies the overt political role of the calypsonian as central to the evolution of politics of the Caribbean.

Not only has calypso served as an unofficial record of historical figures and events, it emerged as a cultural weapon that yielded tremendous sway within the general audiences of the region. Political leaders, from the colonial period through post-independence and the newly globalized

\footnotetext{
${ }^{3}$ Mark Mattern, Acting in Concert: Music, Community, and Political Action (New Brunswick: Rutgers University Press, 1998), 15.

${ }^{4}$ Ibid., 26.

${ }^{5}$ Rex Nettleford, Caribbean Cultural Identity: The Case of Jamaica (New York: Princeton: Markus Wiener Publisher, 2003$), 18$.

${ }^{6}$ Michael Manley, "Reggae and the Revolutionary Faith ... The Role of Bob Marley" in Every Little Thing Gonna Be Alright:

The Bob Marley Reader, ed. Hank Bordowitz (Cambridge: Da Capo Press, 2004), 218.

${ }^{7}$ Quoted in Hollis Urban Lester Liverpool, Kaiso and Society (Virgin Islands: Commission on Youth, 1986), 25.
} 
Caribbean nation states, fear and respect the power of popular culture for conveying and transforming the sentiment of Caribbean politics at an (inter) national level. ${ }^{8}$

Rohlehr also captures the convergence of politics and the calypso within the context of the larger popular culture:

The calypsonian, master and keeper of all verbal codes within popular "Creole" culture, has assumed the role of decoder and un-masker of the new slogans and codes and masks that each regime of political chantwels has ambiguously employed to inspire society with notions of a desired ideal, and to conceal the distressing truth of our lived reality. ${ }^{9}$

Rohlehr (2001) identifies seven major functions of the calypso: worship, battle, work, celebration, social control, praise and popular narration. Although the word "calypso" was not used until the early nineteenth century, the musical form was evident more than a century before. As Rohlehr argues above, despite the many ethno-cultural influences on its evolution, it is generally agreed that the roots of calypso can be traced to the West African musical traditions brought to the Caribbean by the enslaved Africans (Rohlehr 1990, Mason 1998, Liverpool 1986). Rohlehr acknowledges the West African roots are manifested in the traditional African call and response and satire, but he contends that there were other influences along the way. Perhaps the best definition of the calypso comes from Rohlehr, arguably, the leading scholar of the music. According to him: "It is related to all Black diaspora music, regardless of language, and carries with them traditional African functions of affirmation, celebration, protest, satire, praise, blame, conflict of all varieties." 10

Rohlehr contends that the function of social control "is a way of drawing lines and saying that a certain type of behavior either of the average clansman or the ruler himself, has gone beyond socially permissible bounds." 11 The calypsonian then is the critic of the status quo, in particular those at the top who are charged with navigating the ship of state. This function brings the calypsonian performer-critic directly into the political sphere as the protector of political morality and justice. The critic becomes the symbol of political resistance and affirmation by speaking out on behalf of the aggrieved majority, chastising the powerful and articulating new forms of political morality and justice. Rohlehr locates this role in traditional African society and culture: "in many African societies, the singer, the storyteller, the grist, the poet, the man of words is privileged to criticize social foibles." He observes that this function is often carried out with the help of "masking" in which the criticism is done "through a mask of words, imagery, proverbs, fables and so on." ${ }^{\text {"2 }}$ Masking has proven to be a potent tool in the face of government censorship of the right to free speech by both colonial and post colonial governments.

The second function which is applicable to the political calypsonian is the praise function which according to Rohlehr acknowledges the accomplishments of the hero and heroines of the society. He asserts that while the social control songs are the "vehicles of the people's scorn," the praise songs "celebrate the achievement of the hero, however the hero is defined." 13 He also observes that a particular leader is sometimes the object of both social control and praise songs. The third function of the political calypsonian is what Rohlehr refers to as "popular newspaper." Here the calypsonian functions as a reporter and interpreter of events; the singer is both reporter and editor. Rohlehr says this type of calypso "comments on interesting events taking place in the community or society" and he depicts the calypsonian as a "narrator." 14

\footnotetext{
${ }^{8}$ Saunders, "Mapping the Roots/Routes of Calypso," xx.

${ }^{9}$ Gordon Rohlehr, "The Calypsonian as Artist: Freedom and Responsibility." Small Axe 9 (2001): 21 ..

${ }^{10}$ Gordon Rohlehr, Calypso and Society in Pre-Independence Trinidad (Trinidad: Gordon Rohlehr, 1990), 5.

${ }^{11}$ Gordon Rohlehr, Review of "Calypso and Caribbean Identity," in Caribbean Cultural Identities, ed. Glyne Griffin. Bucknell

Review XLIV, no. 2 (2001a): 63.

${ }^{12}$ Ibid.

${ }^{13}$ Ibid., 65.

14 Ibid.
} 
Warner identifies the political calypsonian as one "that monitors what is happening around him and uses the platform of the calypso to expose his listeners a point of view that is not only his personal one, but more often than not is indicative of what the man in the street is thinking about a particular situation." ${ }^{15}$ LaRose refers to the political calypso as music of defiance: "You have kaiso of defiance: a certain kind of defiance, a marching and warrior type of activity within the kaiso." 16

Calypsonians have also weighed in on the socio-political function of the calypso. In "What is a Calypso" (1968), the Mighty Duke, who won the prestigious calypso monarchy in Trinidad and Tobago a record four consecutive years, calls it "editorial in song" which comes from "deep within." He elevates it beyond simply "a work of art" to a music that reflects "suffering and living."

I am sure you don't know what calypso is

The words that we rhyme and sing

Is only half the thing

I could tell you that

Calypso is more than a work of art

It is a feeling which comes from deep within.

A tale of joy or one of suffering

An editorial of the life we living.

Black Stalin, another celebrated political calypsonian, locates the calypso in the universality of the Caribbean experience and sees its primary function as one of resistance. For Stalin calypso is "resistance language"; and a "way of life." Like Duke, he sees the calypso as more than mere music: "You've got to understand, kaiso is more than just a music that's passing through. It's a whole way of life. We could do whatever we want and we still can't get away from kaiso." ${ }^{17}$ David Rudder in his "Calypso Music" (1987) also characterizes the music as something from "deep within." Invoking Rohlehr's "social control" function," he highlights the relationship between the lyrics and the behavior of the politician.

It is a living vibration

Rooted deep within my Caribbean belly

Lyrics to make a politician cringe

Or turn a woman's body into jelly

It is a sweet soca music, calypso

You coulda never refuse it, calypso

It make you shake like a shango now, calypso

Why it is you shaking, you don't know, calypso.

Brother Valentino shares both Rudder's characterization and Black Stalin's universalist function of the calypso. But he identifies another role-the role of the music in shaping popular culture or what he calls "the lifeblood of the people":

The calypso was always the most dominating factor, because it related to the people's lifestyle better than any of the other music. It was your lifestyle; a reflection of a people's lifestyle... Calypso is a thing that could make people hate you or it could make people love you. It could

\footnotetext{
${ }^{15}$ Keith Q. Warner, Kaiso! The Trinidad Calypso: A Study of the Calypso as Oral Literature (Washington D.C: Three Continents Press, 1985), 59.

${ }^{16}$ David Rudder and John La Rose, Kaiso Calypso Music: David Rudder in Conversation with fohn La Rose (London: New

Beacon Books, 1990), 11.

${ }^{17}$ Winthrop Holder, “Nothing Eh Strange: Black Stalin Speaks!” Small Axe 9 (March 2001): 143.
} 
make people cry, it could make people laugh, and it could make a politician cringe according to David Rudder. ${ }^{18}$

Continuing with the larger role of the music beyond the dancehall, Chalkdust views it as both a medium of national unity and a tool of education.

Born in struggle, born out of protest, today the calypso is the medium whereby many groups, ethnic and otherwise, are being united. Today the calypso has become a powerful educational resource used in schools by many teachers from primary to university level, not only to make the lessons more interesting, but to motivate children to learn, and to make them better understand our social, economic and political development. ${ }^{19}$

\section{The Rise of Authoritarian Governance in the Caribbean}

Independence came to the Caribbean courtesy of a nationalist movement that represented a broad consensus among the various segments of the colonized peoples. However, this nationalist fervor would soon unravel as the new post-colonial rulers began to steer independence away from the overriding principles of the independence movement. Lewis contends that "the moment of independence was also a moment of re-colonization" 20 and Bouges calls it "the double transformation of colonialism into post colonialism, then into neo-colonialism."21

This movement away from the independence ideals converged with the coming of age of a new generation of Caribbean scholars. Radicalized by the independence movement and exposed to a new kind of education these scholars were asking questions about the content and direction of independence. They rejected the independence leaders' gradualist approach to change that invariably catered to the imperatives of the former colonizers and advocated instead a decisive break with colonialism and the institution of a political economy that reflected the logic of political independence. In short, therefore, the question was whether independence meant a reform of the colonial order or freedom from its clutches. This standoff proved to be the seed of a second independence struggle that began with the Black Power movement that in turn engendered a radical leftist upsurge in the 1970s. If the earlier independence movement was fueled by the need to get rid of colonial rule, this new movement focused on the need to turn the rights won at independence into real freedoms.

The Black Power movement began with the Rodney incident of October 1968, which resulted from the Jamaican government's decision to ban Walter Rodney, a Guyanese-born historian, from re-entering the country. This action precipitated a local reaction which ignited a movement across the region that would have a decisive impact on the politics of the next decade. The "Rodney Riots" were followed in 1970 by the "February Revolution" in Trinidad, where Black Power demonstrations brought the government to its knees. The movement inspired a cultural renaissance among the African descended peoples that was manifested in a flush of African pride and interest in their African heritage. Second, it ignited a new resistance spirit that would serve as the basis for the broad radical movement that pushed the region to revolutionary action. Third, it inspired a new Caribbean nationalism among the masses based on a shared history and the unity of the ethnic groups.

At the political level the influence of Black Power radicalism engendered a simultaneous rise in autocratic governance. Fearing the spread of radicalism to their countries, most of the governments took a confrontational attitude to the movement. They passed laws aimed at frustrating dissent and in the process

\footnotetext{
${ }^{18}$ Brother Valentino, "Life is a Stage," (2005) http:/www.triniview.com.

${ }^{19}$ Liverpool, Kaiso and Society, 53.

${ }^{20}$ Rupert Lewis, Walter Rodney's Intellectual and Political Thought (Detroit: Wayne State University Press, 1998), xvii.

${ }^{21}$ Anthony Bouges, Black Heretics Black Prophets: Radical Political Intellectuals (New York: Routledge, 2003$), 126$.
} 
trampling on civil liberties such as freedom of the press and freedom of association. Radical leaders were routinely harassed and persecuted and in some cases were assassinated.

While governments in Guyana, Grenada and Dominica were the most extreme in this regard, former St. Lucian Prime Minister, Kenny Anthony observes, the others were not far behind. According to him, the leadership "was intolerant of criticism and, in many instances, did not hesitate to use force to defeat political opponents. Eric Gairy's Grenada and Forbes Burnham's Guyana were only the most extreme examples of these tendencies. The rest of the Caribbean differed from these countries only in quantitative terms. ${ }^{22}$ Civil liberties were routinely undermined, draconian laws were introduced and opposition politicians and other dissenters were routinely harassed, imprisoned and assassinated. In short, government was not accountable to its citizens. These repressive tactics led to a shift in emphasis by the radicals from race to a more class oriented approach that advocated a revolutionary socialism that stressed popular democratic participation in politics and economics.

\section{The particular politics of Trinidad and Tobago}

The political calypso from Trinidad and Tobago cannot be divorced from the socio-political evolution of the country. Trinidad and Tobago gained independence from Britain as part of the decolonization wave that started at the end of the Second World War. Peopled by descendants of African slaves and Indian indentured laborers, the country is demographically different from the other islands. Independence was attained in 1962 under the leadership of the Black-led People's National Movement (PNM) of renowned scholar, Dr. Eric Williams.

Trinidad and Tobago is a union of two islands-Trinidad is the larger partner and Tobago the smaller-with a population of close to two million. Unlike most Caribbean countries the population is divided evenly between Africans and East Indians, the latter came as indentured servants at the end of slavery in the 1830's. As a result of this ethnic makeup the country's politics is determined by ethnic consideration with each group having its own parity and economic sphere. Indians dominate the commercial sector along with the small mixed/white group and the agriculture sector, while Africans dominate the armed forces and government sectors. The PNM held power for thirty years beginning in 1956 when the country gained self-rule from Britain. The PNM held power for such a long period largely due to the ability of the government to use state resources as a trade-off for votes but also because it was able to woo the Muslim faction of the East Indian community. Since 1986 the government has fluctuated between the PNM, the Indian-led UNC and the multiracial NAR.

The early PNM government opted for a politics of accommodation with the west instead of serious transformation of the society. The first decade saw very little change in the material circumstance of the poor. This made the government a target for the radical in the Black Power Movement that swept the Caribbean in the late 1960s and early 1970s. Black Power demonstrations and mutiny in the army led to the "February Revolution" in February 1970 that almost overthrew the government. While the government granted some of the demands of the movement, the revolution was followed by an authoritarian form of governance that saw government pass draconian laws aimed at stamping out dissent. The PNM remained in power partly because the rise in oil prices in the 1970s brought an unprecedented amount of revenue to the country. The government embarked on a program to tackle structural problems such as unemployment and poverty but these invariably became the victims of partisan politics and corruption as PNM supporters were favored.

Because of its oil resources Trinidad and Tobago fared better than its Caribbean neighbors, but since the industry was dominated by foreign companies, the gains did not translate into real sustained development. Despite efforts by the government to control part of the industry and link it to other sectors of the economy, the end result was the continued dependency of the country. By the turn of the 1980s oil

\footnotetext{
${ }^{22}$ Kenny Anthony, At the Rainbow's Edge: Collected Speeches by Kenny D. Anthony 1996-2002 (Kingston: Ian Randle Press, 2004), 236.
} 
production had begun to decrease leading the government to cut back on many of the welfare programs it had instituted. In addition, the death of long time leader Eric Williams in 1981 had a negative effect on the country he ruled for twenty five years with a firm grip. His death left a gaping hole in the political landscape. His successor George Chambers, led the party to victory in the 1981 election, but as the economy stumbled he was portrayed as a weak and uninspiring leader.

Not surprisingly the PNM lost the next election in 1986, by a wide margin. The victor was the newly formed National Alliance for Reconstruction (NAR), which was an alliance of opposition parties and individuals. Significantly the alliance included the East Indian led United Labor Front (ULF) which was the latest version of the Indian party. The party however was led by ANR Robinson, a one time deputy leader of the PNM. The NAR's term coincided with the imminent decline of the economy forcing the government to approach the IMF, which recommended its structural adjustment, including removal of government subsidies, cut in government spending, devaluation of the currency, relaxation of tariffs and increase in privatization. The cumulative effect on the working people was devastating. In addition the NAR was torn by internal rift between the Indian and African factions, with the former charging the Prime Minister with high handed governance. The party eventually split in 1988 when the Indian faction led by Basdeo Panday left.

As was expected the NAR was ousted at the next election and the PNM regained power under a new leader Patrick Manning. The Manning government benefited from some of the economic reforms initiated by the PNM, but like previous leaders the Prime Minister was accused of authoritarianism. Thus after serving one term the PNM was replaced by the Indian led United National Congress. The UNC owed its victory to the actions of the Tobago based Democratic Action Congress (DAC) led by ANR Robinson, which joined an alliance with the UNC after there was a 17-17 tie in Trinidad. Robinson soon became President, a prestigious but largely ceremonial position. The UNC victory was historic, in that it marked the first time that an Indian-led government had come to power. Almost immediately African activists began to charge the government with marginalizing Africans, the same charges Indians made under African-led governments. Another charge leveled against the government was corruption.

The next election held in 2000 resulted in another tie, this time the tie included the Tobago sects. It was left to the President, ANR Robinson to once again make a choice, albeit in a different capacity. This time he chose to ask the PNM to form the government. But the government had to function without a parliament as the UNC refused to cooperate in naming a speaker as a prerequisite for the parliament to convene. Thus, when the budget became due, after a year the government had no choice but to call elections which were won by the PNM. By this time the economy had rebounded, thanks to the discovery of more oil and natural gas. The issue, therefore, is no longer stewardship of the economy, but ethnicity. Since returning to power the PNM has gone after UNC for corruption during its tenure. In the process several UNC functionaries have been prosecuted and found guilty including former Prime Minister Basdeo Panday. Despite the relative health of the economy, Trinidad has become a haven for the drug trade, which has spurred increased crime, violence, and kidnapping.

\section{True Opposition}

For Warner, Chalkdust is the quintessential political calypsonian who saw his role as "principally that of the people's spokesperson." ${ }^{23}$ Comparing him to the Mighty Sparrow, who had been the most outspoken political calypsonian of the previous decade, he observes:

He would call names and point an accusing finger in a way Sparrow has never done and his treatment of pieces of PNM party and society gossip has made his calypsos eagerly awaited and

\footnotetext{
${ }^{23}$ Warner, Kaiso! The Trinidad Calypso, 79.
} 
listened to every year. His melodies are not as catchy and lingering as Sparrow's but the public willingly forgives a weak melody for biting social and political content.

Chalkdust's critique of the status quo, unlike Sparrow's, went beyond anti-authoritarianism to include Black Nationalism, Caribbean Nationalism and social justice. In this regard, Dudley correctly links his emergence to the Black Power movement and portrays him as a "critic of the government." ${ }^{4}$ Rohlehr (2001a) also locates Chalkdust among those calypsonians, who "functioned as monitors of political discourse and behavior."

Chalkdust belongs to the Black Power wave of political calypsonians in Trinidad and Tobago, which includes others such as Black Stalin, Duke, Valentino and Maestro. Warner (1985) refers to these calypsonians as a "new generation, or rather a new spirit of social and political commentators--still in the traditional mold, but with a renewed sense of purpose." 25 Liverpool says that these calypsonians "have sought to give the Africans in Trinidad and Tobago their just reward.” He continues:

Where before, the calypsonians laughed divisively at African cultural traits, especially African forms of religions like the Pocomania, Shango, Vodum and Baptists... today he sings in praise of such African traits, giving the traits themselves a new and acceptable sense of values. ${ }^{26}$

Chalkdust's career literally was born amidst controversy over the limits of the calypsonian's freedom of speech. The independence government, like the colonial government before it, viewed the political calypsonian with suspicion. Attempts at state censorship were countered by the calypsonians' determination to maintain their traditional role of speaking on behalf of the downtrodden and according to Rohlehr, to expand "the space within which their voices might be given fair play." Chalkdust's criticism in song of the then Prime Minister's displeasure with Trinidadians, who left for foreign countries, led to the invocation of a colonial rule which prohibited public servants commenting on politics and from holding more than one job. Chalkdust fought back in song- "Reply to the Ministry" (1969) and "The Letter" (1969) — and in the process forced the government to retreat. For Rohlehr this episode represented a defining moment in the struggle for freedom of speech: "Chalkdust's great contribution to democratic freedom in Trinidad and Tobago lies in the fact that he challenged the ministry, the regulations and the malignant state machine." 27

Chalkdust views his role primarily as the defender of the voiceless and monitor of the status quo. The latter role is captured in several of his calypsos including "Letter to George Weeks" (1976), "Chalkie the Mail Man" (2006) "The Tent is it" (2001) and "They put me so" (1997) and "The Unwritten Law" (2003). "Letter to George Weeks," which advises labor leader, George Weeks, to leave politics and enter the calypso ring, is a commentary on the power of calypso to "educate the populace/ show them the problem that we face." He speaks about the potency of the calypso in keeping the government on its toes and about his own duel with party leader, Eric Williams.

If you want Eric to go

Hit him where it hurts for so

Walk slow

And George come and sing calypso

To knock him out

Hit below

\footnotetext{
${ }^{24}$ Shannon Dudley, Carnival Music in Trinidad: Experiencing Music, Expressing Culture (New York: Oxford University Press, 2004), 29.

${ }^{25}$ Warner, Kaiso! The Trinidad Calypso, 79.

${ }^{26}$ Liverpool, Kaiso and Society, 17.

${ }^{27}$ Rohlehr, "The Calypsonian as Artist," 17.
} 
Like me and Valentino

Punch slow

And Georgie come and sing calypso

In "Chalkie the Mailman" he casts himself as the link between the people and the government. The assumption is that the government is out of touch with the feelings of the people and the people do not have mediums through which they can channel their concerns.

My role as a calypsonian

Is a mailman

To make government understand

How the people thinking

And all what they saying

Bout all them things whey happening

Rohlehr has observed that the calypso tent where the calypsonians ply their trade during the carnival season has evolved into "a sort of popular equivalent to parliament" and a "privileged space" largely as a result of the tenacity of the calypsonians' in defense of their freedom of expression. ${ }^{28}$ In "The Tent is It" (2000) Chalkdust invokes both Rohlehr's image of the popular parliament and Valentino's “True Opposition" (2001) in which the calypsonian is portrayed as the only viable opposition to the government. If he [Chalkdust] stands on the Black Power side of the racial fence, in this calypso he stands on the side of the poor. He elevates the calypso fraternity to the status of a major political actor-as representatives of the socially downtrodden. The calypso is also an indirect criticism of the elite nature of government and governance in the post-colonial Caribbean and the concomitant marginalized of the poor.

I am for PPP

The Poor People's Party

Is them I represent

And the Kaiso tent

Is my parliament

For Chalkdust the representative of the poor should avoid conventional politics and political parties; he/she should not favor one party over the other. The inference here is that despite their rhetoric, there is no difference among them. Even the National Joint Action Committee (NJAC), the Black Power party, is not an option for him. Since he has expressed support for the party in the past, one must assume that his discomfort is with the NJAC that plunged into electoral politics in the 1980s. He elaborates on this theme in "Too Much Party" (2004). Joining the political parties, then, has not been an option for Chalkdust. He sees them as "rats" which use people as "mats." He also would not be bought by promises of material wealth from the politicians who he does not equate with fairness or justice.

I am no door mat

For them Red House Rats

Car, house and loot

I don't give a hoot

I prefer truth

And men of repute

I am for fairness

\footnotetext{
${ }^{28}$ Ibid., 20-21.
} 
And justice

I am for people

Black, White or Purple

\section{Chalkdust vs. Eric Williams and the Government}

This government highhandedness naturally found its way into the calypsos. So relentless were the calypsonians on the subject, Brother Valentino dubbed them "the true opposition." Generally, the calypsos tended to fall into two broad categories-exposure and denunciation. The former highlighted scandals such as government corruption and conflicts of interest while the latter often took the government to task for these and other transgressions.

Chalkdust music/lyrics emerged as a consistent critic of government highhandedness, its betrayal of its nationalist obligations and its neglect of the poor and the powerless. This three-pronged approach meant that Chalkdust was simultaneously exposing the government, telling the story of the oppressed and advocating a new nationalism. It also meant that he had the government "cornered" at all times. His view of Caribbean leaders is aptly captured in one of his later calypsos, "Caribbean Leaders" (1998):

Caribbean leaders are all the same

Power gone to their head

Because they rule a piece of earth

They feel they possess some worth

In one of his signature calypsos, "Ah put on me guns again" (1976), Chalkdust targets the government's highhandedness as the main reason for his decision to return to the calypso arena. He zeroes in on the government's dismissal of top civil servants who disagreed with it. According to Chalkdust when "the board at Telco tell Ivan Williams to go," when the Prime Minister, Eric Williams, "run Mr. Irwin Merritt from the State and the Senate," when "big boys are charged and then discharged," and "when the auditor show ten million gone for so" he "put up his guns again." He has taken the role of the "attackdog" seriously as evidenced in the opening stanza of "Ah put on me guns again":

Back in '68

When I start to sing calypso

I used to shoot straight

All my enemies I kill slow

I would shoot right and left

Big shot men met their death

One of those who met his death was Karl Hudson-Phillips, the then Attorney General and Prime Minister in-waiting. Perhaps Chalkdust's best known calypso, "A Fraid Karl" (1972), is thought to have had a decisive impact on the political career of Hudson-Phillips, who is portrayed in the calypso as a dictator and a "seditioner" that the society should be afraid of. The "seditioner" is a reference to the sedition laws passed under Hudson-Phillips' watch as part of the government's wider use of the legal system to stem the growing dissent. When Eric Williams announced his intention to step down as leader, Hudson-Phillips was thought to be his logical successor. But Williams changed his mind, setting in train a rapid decline of Hudson-Phillips' influence in and eventual exit from the party. Although he would reemerge in the 1980s as the leader of an opposition party, the Organization of National Reconstruction (ONR), he never regained the same status in the political arena. Regis agrees that Chalkdust's calypso effectively ended Hudson-Phillips' political ambitions for the top job: 
Chalkdust's "Ah Fraid Karl” (1972) effectively destroyed any ambitions Hudson-Phillips may have had of becoming prime minister. It impresses horrifying images on the collective psyche which was prepared for them. ${ }^{29}$

Chalkdust made much of the rift between Dr Williams and Hudson Phillips as he pitted the ambitious, power-hungry pretender to the throne against the spiteful master-leader. In "PNM loves me" (1973), he opined that Williams was also afraid of Hudson-Phillips: "And it's not Chalkie alone pal/ I and all 'fraid Karl." Chalkdust does something interesting in that line-he presents Williams as "fearful," a characterization that was inconsistent with the leader's invincibility. He also asks in "Clear you Name" (1974), "Did you retain your post in order to spite Karl?"

In what became Chalkdust's trademark approach, he uses Hudson- Phillips as the medium through which he launches an attack on government overreach. This is what Rohlehr calls "masking" and Chalkdust describes as "spinning from the back of the hand," a cricketing reference to the guile of the leg spinner, perhaps of the most complex bowler in the game. Here the calypsonian assumes the role of the reporter, or Duke's editorial writer, as he exposes scandals in the government.

They say a young minster was found

In a hotel with a call girl in town

But I aint singing about that...

Ah 'fraid the seditioner...

They say PNM was nearly wrecked

By the secretary and his rubber check

But ah 'fraid, I don't know

It is in this context of opposition to government over-reach that Chalkdust, more than any other calypsonian, became a thorn in the side of the PNM government and its leader, Dr. Eric Williams. He would later apply the same standard to other governing parties and their leaders, even though it could be argued that he has not been as obsessed with other leaders as he was with Dr Williams. A close reading of his calypsos reveals a consistent attempt to unmask and disrobe the leader, to "cut him down to size." Several of Chalkdust's calypsos were severely critical of the Prime Minister, Eric Williams. These include "Somebody Mad" (1973), "Goat Mouth Doc" (1972), "Two Sides of the shilling" (1971), "Clear Your Name" (1974) and "PNM Loves Me" (1973) in which he portrayed the Prime Minister as being, among other things, mad, dictatorial, out of touch and foolish. Williams reportedly hit back at the calypsonian by labeling him a "jackass." This is part of what Rohlehr refers to as the threat and counter-threat between the politician and the calypsonian.

Regis (1999) locates the "Chalkdust-Williams feud" in the government efforts to censor him in 1968. He, however, opines that Chalkdust had an ambivalent attitude to Williams. Although his criticism of the Prime Minister was harsh, he nevertheless acknowledged that he was a man of tremendous worth in calypsos such as "Let the Jackass Sing" (1974) and "Ah can't bury Williams" (1999). His extreme antiPNM-Williams calypsos, therefore, were not driven by dislike of Williams the person but of his politics, particularly on issues relating to race and class. Chalkdust in "Ah can't bury Williams," locates his criticism of Williams within the traditional role of the calypsonian: "To attack Williams in calypso was traditional."

Regis thinks Chalkdust's ambivalence towards Williams stemmed from the Prime Minister's policies on education and the development of calypso, a view that Chalkdust himself seems to share. However, another explanation lies in Chalkdust's generation dismay at the contradictory praxis of Williams' generation of leaders-the contradiction between their anti-colonial heroism and their post-colonial conformism and anti-independence. This contradiction was at the heart of the Black Power movement's critique of where independence was headed-why those leaders who marched with the lower class for

${ }^{29}$ Louis Regis, The Political Calypso: True Opposition in Trinidad and Tobago 1962-1987 (Jamaica: The Press University of the West Indies, 1999), 101. 
independence had turned against worker organizations? Why those who maligned the colonialists and imperialists in the 1950s were accommodating and mimicking their policies and governance style in the 1960s? Why those who railed against white racism were now preserving the same racist power structures? These questions were central to Chalkdust's praxis-a combination of anti-authoritarianism or revolution democracy and Black Power. Calypsos such as "We are ten years old" (1972), "Massa day done" (1974) and "Ah put on me guns again" (1976) reflected this duality. Chalkdust himself puts his attitude to Williams in perspective in this quotation:

I disliked some of the policies that seemed to ignore lessons of history with respect to destructive effects of Capitalism and Imperialism and its accompanying racism and degrading of black people, yet I admire him for his beliefs and practices of non-discrimination on grounds of race, color or beliefs. While I dislike him for trying to solve all problems by historical documentation and use, and while I abhor him for taking lots of burrowed ideas historically developed and used by others and replanting them wholesale in our society, I am proud to have been a schoolboy in Eric Williams' heyday for it was his application to study, and his love of the academic disciplines that fired my thinking process and helped me to arrive at the decision that I too shall become a historian. ${ }^{30}$

In "Clear Your Name" (1974) Chalkdust launched his most stinging attack on Williams by calling on the Prime Minister to refute the many rumors associated with both his personal and political life. As was the case with "A Fraid Karl" the calypso recounts a litany of charges which the calypsonian compares to the "Watergate" scandal in the USA:

For seventeen long years you've stayed in power

But soon you'll have to go

But many things happened under you doctor

That all of us don't know

Though most of it may be just plain rumor

Doc if you must remain great

Before you go please clear the air

With a local Watergate

While the calypso was highly critical of Williams, it was simultaneously a subtle acknowledgement of Williams' exalted place in Trinidadian and Caribbean history. This seeming ambivalence towards Williams speaks to his dual and contradictory role in Caribbean politics. On the one hand he is the messenger of freedom, the educated hero-intellectual whose clarion call, "Massa day done," mobilized the nationalist upsurge that gave hope to the oppressed. But he is also the maximum leader who behaved like a modern massa, the villain whose actions invited skepticism from his followers and derision from his detractors. Chalkdust puts this hero-villain attitude towards Williams in giant-jackass terms:

In the near future our young children will study you in class They would want to know if you were a giant or simply a jackass

I hope Doctor that they will find you a man of integrity

But to hold a place in all history Doc answer me truthfully

Chalkdust also zeroes in on the need for open government. He suggests that the legendary secrecy that surrounded Williams was bad for government accountability. In the process he makes two important linkages. First, he argues for a linkage between the "great intellectual" and good governance; he "begs" Williams to be guided by the "giant" in him rather than the "jackass." Second, he sees the relationship

\footnotetext{
${ }^{30}$ Quoted in Regis, The Political Calypso, 152.
} 
between leader and the people as critical to evaluating quality of leadership. Drawing on his own training in history and playing on Williams' stature as a reputable historian, he frames his argument in historical terms:

You know from history that many great men

Have gone on to lose their fame

For they were hiding secrets from people

Or rumors of their name

So Dr. Williams I beg you kindly Sir

As a great intellectual

Let your life be an open book

To be seen and read by all

In "Somebody Mad," he portrays Williams as a madman whose madness was responsible for what Chalkdust sees as bad government policies on housing, taxes, culture and spending on soldiers who mutinied during the February revolution. The image of the madman is prevalent in Caribbean popular culture. Black Stalin invoked it as a possible characterization of his dream of an African nation and David Rudder's "Madman Rant" (2001) portrays the madman as the voice of sanity. As usual Chalkdust creates a character through which he conveys his message-his mask. In this instance, the mask is Dr. Bharrat, a psychiatrist.

In the oval to see Pele match

I sat next to Dr. Bharrat

We had a long talk, I said listen Doc

You know about mad people a damn lot

Round the world you does travel

To study insane people

But Doc why do you go overseas

When we have mad men here like peas

The government's decision to locate a housing complex in close proximity to a garbage dump is depicted as gross madness.

Well then if a man could watch the labass right there

And build houses so near

for people to stay

To take in that stinking stench the whole day

Somebody would have to be mad

Somebody up in the White Hall mad

He compares a decision to send female models instead of calypsonians and steel-pan players to a cultural event abroad to a calypsonian going to USA to sing soul music instead of calypsos.

If I should teach a Nigerian

To model a dashiki

I say you mad

And if Chalkie went to Washington

To sing soul and rock steady

I say you mad

Well then if a man 
Could leave calypso and pan

To represent us up in Switzerland

And send six girls to model their behind

Somebody have to be mad

Finally, he takes the government's tax policy to task. In particular, he criticizes its impact on the poor. Here Chalkdust highlights the moral and political responsibility of the government to help the weak and implicitly favor less taxation for the poor. This was a critical issue in Trinidad and the rest of the Caribbean in the 1970s as governments sought to find ways to raise revenues while trying not to alienate private capital. In Trinidad, which imported a considerable amount of its food items, prices on the retail market tended to be higher than in some of the other countries in the region. Chalkdust correctly makes the linkage between taxes and high prices of basic food items.

If I turn down a hungry man

Even though I have cash on me

I say you mad

Allright, and I if I watch that very man

And take away his money

I say you mad

Well then, if every year a man taxing we skin

Bread, butter, milk, oil, gas, and rum raisin

Although we are jobless, poor and scrunting

Somebody would have to be mad

Somebody up in White Hall mad.

Although Chalkdust denies that he was speaking about the Prime Minister, he makes the reference to Whitehall, the offices of the Prime Minister. His reference to Williams' education, even as he portrays him as insane, points to the duality of Williams in the popular consciousness.

Doctor Bharrat now get this straight

I am not talking about Eric

I don't connect him with insanity

Cause he went to a university

"PNM loves me" targets government concealment of unfavorable acts by its members, highlights the Prime Minister's high handedness and the willingness of the top leadership to bow to his wishes. In effect the calypso points to the lack of democracy in the political party. He enumerates the government's abuses through the voice of the Public Relations Officer, who finds himself in disagreement with the General Council over a move initiated by the latter to admit Chalkdust to the PNM. Whereas the General Council favors admitting Chalkdust, the PRO and the Prime Minister are against such a move. This has been an issue in Caribbean politics-whether to bring rebels into the fold of the party as a means of neutralizing them or keep them outside for fear that once inside they would expose "party secrets." The PRO's resistance is based on the fear that Chalkdust would reveal such secrets:

Merritt say, If you love him bring him in

But be prepared for anything

Like alyou want the public to get to know

That we fired Jean Miles from White Hall just so

Cause she slap up a Minister who tried to kiss her

If you want the nation to know the truth

How Karl beat Eric in his libel suit 
And Eric have to pay him plenty money to boot

Well then Merritt say it's no big thing

Bring him in

Chalkdust draws a line between the membership and the leadership; he portrays them as endorsing his criticism of the party,

The people in PNM love me

Although Merritt warned them

They say let's make him a member still

To shake up the PNM

They say if men like Chalkie were inside here

The big boys would have a scare

And we would get to know the PNM members

Who thief Special Works money in St. Clair

The Prime Minister's response to the news that the General Council voted to admit Chalkdust highlights Dr. Williams' authoritarian grip on the party,

But when Eric heard the great good news

He nearly charged him for sedition

He told him go and tell the Trinidad Guardian

We reject the application

History proves that I must keep incompetent men

To remain in my high position.

Almost two decades later Chalkdust's "The driver cannot drive" (1989) captured the popular sentiment towards the National Alliance for Reconstruction (NAR) government, which had won a landslide victory against the almost invincible People's National Movement (PNM) but soon ran into trouble amidst a declining economy and political infighting. The Prime Minister, ANR Robinson, a former deputy leader of the PNM under Williams, was depicted as an incompetent taxi-driver: "It took a year for passengers to realize/they say the new driver cannot drive"

In this calypso, Chalkdust assumes the role of the political economist as he critiques the government for abandoning economic independence in favor of the International Monetary Fund (IMF)/World Bank structural adjustment program and implementing harsh anti-people policies that erased some of the social programs implemented by the previous government. Here he is recognizing the onset of globalization and its potential negative consequences for the working people in the Caribbean. He also highlights the impact on education and social safety-net programs such as the Cost of Living Allowance (COLA), but he is also faulting the government for caving in so easily to the dictates of the IMF.

The dictatorial politics of the wider Caribbean are also captured in this calypso-he draws attention to excesses of the Eric Gairy government in Grenada, which had resorted to, among other things, using violence against its opponents: "In Grenada the Mongoose plot and kill Bishop." The "mongoose" he refers to is the infamous Mongoose Gang, a para-military force that served as the personal "army" of the Prime Minister while Bishop, the father of Maurice Bishop, died after he was beaten by members of the mongoose gang during an anti-government demonstration.

\section{Conclusion}

It is difficult to gauge the extent to which Chalkdust's calypsos influenced public opinion or whether they had any influence at all. But as a radical critique of the political order, they are an important part of 
the larger narrative of resistance. The popularity of the calypsonian in the wider society meant that this radical critique reached wider audiences than other mediums of communication. Further, because the calypsonian, unlike the politician, does not seek the votes of the listeners, he or she stands a better chance of engaging the attention of even supporters of the government.

The anti-government critique in Chalkdust's calypsos exposes the sometimes hidden authoritarianism in the Anglophone Caribbean. The region's avoidance of military coups and other forms of dictatorial rule has tended to mask the authoritarian nature of the political order. Consequently it is viewed as one of the most democratic regions of the world. Chalkdust's calypsos challenge that assumption by taking the listener beneath the veneer of liberal democracy. This is a delicate undertaking in a region where political dissenters have been victimized by governments, which have been relatively successful in deeming its critics enemies of the state. What is even more important about the political calypso is its ability to record and articulate the plight of opposition political activists.

The calypsos, which highlight the plight of the poorer social classes and berate the government for either ignoring them or for enacting policies which exacerbate their condition, are also part of this radical critique. These calypsos are grounded in a larger critique of post-independence Caribbean governments which have adopted a pro-capitalist economic approach. Black poverty, for example, is portrayed by Chalkdust as the consequence of government neglect and policies that militate against the interests of the Black working class.

Finally, as the most overt of the political calypsonians in Trinidad and Tobago, Chalkdust ventures into forbidden areas of anti-government criticism such as holding up the Prime Minister to scrutiny and ridicule. This is particularly significant in the case of Dr. Eric Williams who was a god-like figure in the country. That Chalkdust was able to penetrate his aura through a combination of wit, humor, rumor, and political critique, points to the power of popular music as a potent form of political protest. 


\section{References}

Anthony, Kenny. At the Rainbow's Edge: Collected Speeches by Kenny D. Anthony 1996-2002. Kingston: Ian Randle Press, 2004.

Bouges, Anthony. Black Heretics Black Prophets: Radical Political Intellectuals. New York: Routledge, 2003.

Brother Valentino. "Life is a Stage” (2005). http:/www.triniview.com.

Dudley, Shannon. Carnival Music in Trinidad: Experiencing Music, Expressing Culture. New York: Oxford University Press, 2004.

Holder, Winthrop. “Nothing Eh Strange: Black Stalin Speaks!” Small Axe 9 (March 2001): 140-258.

Lewis, Rupert. Walter Rodney's Intellectual and Political Thought. Detroit: Wayne State University Press, 1998.

Liverpool, Hollis Urban Lester. Kaiso and Society. Virgin Islands: Commission on Youth, 1986.

Manley, Michael. "Reggae and the Revolutionary Faith . . The Role of Bob Marley" in Every Little Thing Gonna Be Alright: The Bob Marley Reader, ed. Hank Bordowitz. Cambridge: Da Capo Press, 2004.

Mason, Peter. Bacchanal! The Carnival of Trinidad. Jamaica: Ian Randle Publishers, 1998.

Mattern, Mark. Acting in Concert: Music, Community, and Political Action. New Brunswick: Rutgers University Press, 1998.

Nettleford, Rex. Caribbean Cultural Identity: The Case of Jamaica. New York: Princeton: Markus Wiener Publisher, 2003.

Pratt, Ray. Rhythm and Resistance: Explorations in the Political Uses of Popular Music. New York: Praeger Publishers, 1990.

Regis, Louis. The Political Calypso: True Opposition in Trinidad and Tobago 1962-1987. Jamaica: The Press University of the West Indies, 1999.

Rohlehr, Gordon. Calypso and Society in Pre- Independence Trinidad. Trinidad: Gordon Rohlehr, 1990. . "The Calypsonian as Artist: Freedom and Responsibility." Small Axe 9 (2001): 1-26.

Rohlehr, Gordon. Review of "Calypso and Caribbean Identity." In Caribbean Cultural Identities, ed. Glyne Griffin. Bucknell Review XLIV 2 (2001a): 55-72.

Rudder, David and John La Rose. Kaiso Calypso Music: David Rudder in Conversation with John La Rose. London: New Beacon Books, 1990.

Saunders, Patricia. "Mapping the Roots/Routes of Calypso in Caribbean Literary and Cultural Traditions." In Pauchet Paquet et al Music Memory Resistance: Calypso and the Literary Imagination. Kingston: Ian Randle Publishers, 2007.

Warner, Keith Q. Kaiso! The Trinidad Calypso: A Study of the Calypso as Oral Literature. Washington D.C: Three Continents Press, 1985. 


\section{Calypsos Cited}

David Rudder-“Calypso Music” (1987)

Chalkdust_-"The Mailman” (2006)

Chalkdust- "Reply to the Ministry" (1969)

Chalkdust_- "The Letter" (1969)

Chalkdust_- "Caribbean Leaders" (1998)

Chalkdust_-“Ah put on me guns again” (1976)

Chalkdust_- "Ah Fraid Karl" (1972)

Chalkdust_-"PNM loves me" (1973)

Chalkdust_- "Clear you Name" (1974)

Chalkdust_-"Somebody Mad” (1973)

Chalkdust_- "Goat Mouth Doc" (1972)

Chalkdust-“Two Sides of the shilling” (1971)

Chalkdust_- "Let the Jackass sing” (1974)

Chalkdust_- "Ah can't bury Williams” (1999)

Chalkdust_-"We are ten years old" (1972)

Chalkdust_- "Massa day done" (1974)

David Rudder_-"Madman's Rant" (2001)

Chalkdust_- "The driver cannot drive" (1989)

Chalkdust_- "Letter to George Weeks" (1976)

Chalkdust_- "The Unwritten law” (2003)

Mighty Duke- "What is Calypso" (1968) 